\title{
Tinjauan Filsafat Kesehatan Reproduksi
}

\section{Farida Mutiarawati Tri Agustina*}

\begin{abstract}
Abstrak
Kesehatan reproduksi tidak dapat dipisahkan dari kesehatan seksual yang menyangkut peran dua aktor utama laki-laki dan perempuan yang harus dalam kondisi sehat untuk mendapat hasil reproduksi yang sehat. Dari sudut pandang filsafat, ontologi berupaya memahami, mendalami dan mengembangkan pengetahuan kesehatan reproduksi pada tingkat individu dan tingkat masyarakat. Secara epistemologi, kesehatan reproduksi banyak mengalami kemajuan, sejak dari teknologi kontrasepsi sederhana sampai teknologi cloning yang kontroversial. Secara aksiologi, kesehatan reproduksi mampu meningkatkan kesejahteraan dan pemenuhan kebutuhan hidup manusia sesuai perkembangan teknologi. Pemanfaatan dan keberhasilan kesehatan reproduksi dipengaruhi berbagai faktor yang saling terkait dan saling tergantung. Landasan perkembangan ranah kesehatan reproduksi adalah serangkaian konferensi kependudukan dunia sepuluh tahunan. Dimulai pada tahun 1954 di Roma, dilanjutkan 1965 di Belgrade, 1974 di Bucharest, 1984 di Mexico City, dan terakhir tahun 1994 di Cairo. Hingga kini, penerapan berbagai hasil konferensi untuk peningkatan kesejahteraan umat manusia terus berlangsung. Di seluruh negara di dunia, diharapkan hak-hak kesehatan reproduksi dan kesehatan seksual semakin dipenuhi dengan pemanfaatan maksimal teknologi dan sesuai norma dan nilai-nilai kemanusiaan yang adil dan beradab.
\end{abstract}

Kata kunci : Kesehatan reproduksi, tinjauan filsafat.

\begin{abstract}
The Reproductive Health can not be separated from Sexual Health as there is two main actors of male and female has to be related to. Both of them are must be in a healthy condition, in order to produce a healthy reproductive result. From philosophies stand point, the ontology of reproductive health is tried to understand, to explore and to develop reproductive knowledge in the individual and community levels. Epistemologi of reproductive health show highly progress related to contraceptive technology starting from the simplest one to the most controversial of cloning technology. Axiologically, the reproductive health enables to improve the human prosperity and fulfill the human needs in association with technological development. The utilization and the successfull of reproductive health are determined by several interrelated and interdependent factors. The fundamental of reproductive health field development is in a series of world population conferences that held every tens years. Started in 1954 in Roma, continues to 1965 in Belgrade, 1974 in Bucharest, 1984 in Mexico City, and the latest in 1994 in Cairo. Until now, the implementation of several conference results for improvement of human kind properties is continuously occurred. All over the world, it is hoped that reproductive rights and sexual rights can be continuously fulfilled with a highest utilization of technology and in the line with fairness and enlightened norms and values.
\end{abstract}

Key words : Reproductive health, philosophical foundation.

*Departemen Biostatistik dan IImu Kependudukan Fakultas Kesehatan Masyarakat Universitas Indonesia, Gd. A Lt. 2 FKM UI, Kampus Baru UI Depok 16424 (e-mail: farida_mta@yahoo.com) 
Berbagai masalah kesehatan reproduksi mulai menjadi topik perhatian ketika penyakit HIV/AIDS muncul pada awal tahun 80-an. Namun, area kesehatan reproduksi sudah menjadi program utama kesehatan jauh sebelum itu, sejak era Maria Stopes (1880-1958) dan Margaret Sanger (1883-1966). Maria Stopes adalah seorang bidan Inggris yang mengabdikan diri bagi penduduk pengendalian kesuburan penduduk miskin.1,2 Sedangkan, Margaret Sanger adalah seorang perawat Amerika Serikat yang berjuang mengatur kelahiran untuk meningkatkan kesejahteraan keluarga. ${ }^{3,4}$ Kiprah kedua tokoh keluarga berencana tersebut menjadi tonggak sejarah kesehatan reproduksi di dunia. Angka kematian ibu akibat kehamilan, persalinan dan masa nifas yang tinggi telah membuka mata dunia tentang peranan kesehatan reproduksi yang penting dalam perencanaan keluarga. Dia ditawarkan menjadi alternatif pemecahan dalam upaya meningkatkan kesehatan dan kesejahteraan keluarga. Perencanaan jarak dan jumlah kelahiran terbukti mempu menghindarkan ibu dari kematian yang tragis. Selanjutnya, upaya menjaga kesehatan ibu dan bayi dalam kandungan (kehamilan) berperan menurunkan risiko kesakitan dan kematian ibu dan bayi yang dikandungnya. Hal tersebut tersirat pada berbagai jargon filosofis masa kehamilan yang diciptakan WHO, seperti 'safe motherhood -penyelamatan masa kehamilan', 'making pregnancy safer - membuat kehamilan aman' atau 'every pregnancy is a risk - setiap kehamilan berisiko'. ${ }^{5}$ Keadaan akan semakin diperparah jika pada masa kehamilan terjadi hambatan mengakses pelayanan kesehatan.

Hingga kini, kegiatan reproduksi manusia tidak terlepas dari peran dua aktor utama sepasang anak manusia yang berbeda jenis kelamin yang pada gilirannya akan menghasilkan manusia baru. Untuk memainkan peran tersebut secara baik, kegiatan reproduksi tersebut sudah harus dipersiapkan sejak masih di dalam kandungan. Selanjutnya siklus kehidupan (life cycle) dijadikan metode pendekatan penting dan efektif dalam ranah kesehatan reproduksi. Perkembangan teknologi kedokteran terkini mengantarkan pada cloning yang memungkinkan terciptanya manusia baru tanpa peran hubungan seksual laki-laki. Namun, hal tersebut masih menjadi polemik pro dan kontra berkepanjangan, seperti tersirat dari ungkapan berikut "Cloning is the process of creating an identical copy of something. In biology, it collectively refers to processes used to create copies of DNA fragments (molecular cloning), cells (cell cloning), or organisms. The term also encompasses situations whereby organisms reproduce asesxually." "Cloning describes the processes used to create an exact genetic replica of another cell, tissue or organism. The copied material, which has the same genetic makeup as the original, is referred to as a clone. The most fa- mous clone was a Scottish sheep named Dolly."7

Kontroversi kloning menyebabkan berbagai kalangan agamis atau rohaniwan menentang penciptaan makhluk identik baru melalui teknologi cloning, "The Catholic Church and various traditionalist religious groups oppose all forms of cloning, on the grounds that life begins at conception." 8 Meskipun demikian, penelitian lanjutan masih berlangsung dalam teknologi kloning, terutama pada cloning therapeutic, yang menggunakan stem cell dari sel sehat untuk melakukan replika pada sel-sel yang rusak sehingga sel baru dan sehat akan menggantikannya. Tentu saja hal tersebut sangat bermanfaat penyembuhan berbagai penyakit yang masih sulit disembuhkan, seperti penyakit jantung koroner atau berbagai komplikasi diabetes.

\section{Pengertian}

Jika dilihat dari program kesehatan, maka program kesehatan reproduksi di dunia, meliputi berbagai komponen yang meliputi kesehatan ibu dan anak (KIA), keluarga berencana $(\mathrm{KB})$, kesehatan reproduksi remaja (KRR), infeksi saluran reproduksi/infeksi menular seksual (ISR/IMS), termasuk HIV dan AIDS, serta kesehatan lanjut usia (lansia). Tulisan ini mencoba melakukan eksplorasi tentang perjalanan ranah kesehatan reproduksi dalam keilmuan kedokteran dan kesehatan. Pembahasan akan bermula dari asal kata dan definisi kesehatan reproduksi, dilanjutkan dengan penelaahan ontologi, epistemologi, dan aksiologi kesehatan reproduksi, serta perkembangan ranah kesehatan reproduksi. Makna kata-kata kesehatan reproduksi ditatap berdasarkan aturan bahasa dan definisi lembaga kesehatan dunia (WHO).

Kesehatan Reproduksi terdiri dari dua kata, yaitu 'kesehatan' dan 'reproduksi'. Kata kesehatan, yang terdiri dari kata dasar 'sehat' atau "healthy" termasuk dalam kelompok kata sifat. Sehat adalah suatu kondisi yang bebas dari gangguan, kelainan, atau kesakitan/penyakit pada sistem, fungsi dan proses kehidupan. Jika diberi awalan ke- dan akhiran -an maka kata 'sehat' berubah menjadi kata benda, yang abstrak, 'kesehatan' atau "health" didefinisikan oleh WHO: " Health is a state of complete physical, mental and social well-being and not merely the absence of disease or infirmity." ' 'Kesehatan' merupakan kata benda yang abstrak karena dia tidak berwujud tetapi kehadirannya dapat dirasakan secara nyata oleh manusia. Perasaan sehat atau yang tidak sehat dapat diukur derajatnya. Kita sering mendengar atau membaca pernyataan "ditengarai bahwa derajat kesehatan masyarakat di daerah ' $\mathrm{X}$ ' sangat buruk atau dalam kondisi yang mengkhawatirkan". Selanjutnya, kata 'reproduksi' jelas mengadopsi bahasa Inggris 'reproduction' (kata benda) menjadi 'reproductive' sebagai kata sifat karena berperan memberikan sifat kepada kata 'he- 
alth', sehingga menjadi reproductive health, bukan reproduction health. Reproduksi, terdiri dari awalan reyang artinya pengulangan dan kata 'produksi', sehingga arti kata reproduksi adalah suatu produksi yang berulang atau memproduksi kembali. Dalam dunia kesehatan, reproduksi berarti menghasilkan produk yang serupa dengan spesies induknya. Dalam kamus Thesaurus disebutkan bahwa kata 'reproductive' termasuk dalam adjective atau kata sifat yang berarti "producing new life or offspring." 9

Definisi kesehatan reproduksi yang digunakan saat ini adalah turunan atau pengembangan dari definisi kesehatan yang ditetapkan oleh WHO. Selanjutnya, pada konferensi internasional ICPD di Cairo 1994, definisi tersebut dibakukan dan disetujui oleh para peserta konferensi Reproductive health is "a state of complete physical, mental, and social well-being and not merely the absence of disease or infirmity in all matters relating to the reproductive system and its functions and processes." 8 Dalam bahasa Indonesia, kesehatan reproduksi adalah "suatu kondisi sehat menyeluruh meliputi fisik, mental dan kesejahteraan sosial, tidak semata-mata karena ketidakhadiran penyakit dan cacat yang berkaitan dengan sistem, fungsi dan proses reproduksi”. Dengan implikasi bahwa reproduksi seseorang dinyatakan sehat ketika dia mampu mendapatkan kehidupan seksual dan reproduksi yang aman, mampu bereproduksi, dan bebas menentukan kapan dan seberapa sering bereproduksi. Berarti bahwa hak-hak kesehatan reproduksi seseorang harus terpenuhi dalam menunjang pencapaian reproduksi yang sehat. ${ }^{10,11}$

Secara jelas dapat dilihat bahwa untuk dapat hamil maka dibutuhkanlah sepasang manusia dengan jenis kelamin yang berbeda, laki-laki dan perempuan. Selanjutnya, proses reproduksi tersebut akan diawali dengan pertemuan sperma dengan sel telur yang perkembangan selanjutnya terjadi di dalam rahim perempuan, berkembang menjadi janin, dan sampai pada masa tertentu (sekitar 9 bulan), janin tersebut siap dilahirkan menjadi seorang bayi atau manusia baru. Dalam perkembangan teknologi kedokteran, ternyata suatu mahluk baru atau anak dapat dihasilkan tanpa proses pertemuan sperma dan sel telur yang dikenal dengan teknologi kloning. Teknologi tersebut telah sukses diuji cobakan pada biri-biri yang dikenal sebagai Dolly. Sebagaimana teknologi bayi tabung, sejatinya teknologi kloning bertujuan menolong pasangan yang tidak mampu untuk menghasilkan keturunan dengan cara yang lazim. Dalam kondisi reproduksi yang tidak sehat, sepasang suami istri tidak dapat menghasilkan keturunan. Teknologi kloning ini merupakan terobosan teknologi kesehatan reproduksi di dunia.

\section{Tinjauan Filsafat}

Dalam filsafat ilmu, suatu disiplin ilmu dapat dinyatakan sebagai pengetahuan, jika memenuhi kriteria ontology yang mencakup apa/hakikat ilmu/kebenaran/ Ilmiah, epistemology mencakup metode dan paradigma serta aksiologi mencakup tujuan/nilai-nilai imperatif/sikap (attitude). ${ }^{12}$ Filsafat ilmu berkembang dari dua cabang utama meliputi filsafat alam dan filsafat moral. Filsafat alam menjadi rumpun ilmu-ilmu alam (natural sciences) sedangkan filsafat moral menjadi rumpun ilmu-ilmu sosial (social sciences). Selanjutnya, kelompok ilmu-ilmu alam mempunyai cabang utama ilmu alam (physical sciences) dan ilmu hayat (biological sciences). Cabang ilmu-ilmu alam yang menunjukkan ilmu kedokteran dan kesehatan berada pada garis cabang keilmuan ilmu hayat. ${ }^{13}$

Ilmu senantiasa berkembang, bagaikan pohon yang semakin membesar, tumbuh cabang, anak cabang, ranting hingga semakin rimbun. Hal tersebut disebabkan oleh manusia memiliki rasa ingin tahu yang besar serta ditunjang oleh perkembangan ilmu pengetahuan yang lain seperti kimia, fisika dan teknologi. Dalam The New Britannica Encyclopedia, pohon ilmu mempunyai lima cabang, yaitu Logika (Logic), Matematika (Mathematics), Ilmu Alam (Natural Sciences), Sejarah dan Humaniora (History and Humanities), dan Filsafat (Philosophy). Selanjutnya, cabang Ilmu Alam mempunyai ranting-ranting keilmuan Sejarah dan Filsafat Ilmu (History and Philosphy of Science), Ilmu-ilmu Fisika (Physical Sciences), Ilmu Bumi (Earth Science), Ilmu-ilmu Biologi (Biological Sciences), Ilmu Kedokteran dan disiplin ilmu yang tergabung di dalamnya (Medicine and affiliated disciplines), Ilmu Sosial dan Psikologi (Social Sciences and Psychology), dan Ilmu-ilmu Teknik (Technological Sciences). Dalam Ilmu-ilmu kedokteran, dibahas tentang sejarah ilmu kedokteran (history of medicine), bidangbidang praktek atau penelitian medis khusus (field of specialized medical practise or research), dan disiplin ilmu yang tergabung dalam ilmu kedokteran (disciplines of affiliated with medicine). ${ }^{14}$ Sumber lain juga menyebutkan bahwa ilmu Kedokteran termasuk dalam cabang Biologi Terapan yang bertujuan untuk meningkatkan kesejahteraan manusia, disamping Ilmu Gizi dan Kesehatan/Higiene, Pertanian, Peternakan, Perikanan, serta Bioteknologi. Kemudian dari ilmu Kedokteran tersebut muncul ilmu-ilmu spesifik lainnya, seperti spesialisasi saraf, mata, kandungan, gigi, THT, internis, dan anak. ${ }^{15}$

Pada abad penalaran, konsep dasar keilmuan berubah dari kesamaan menjadi pembedaan khususnya antar berbagai pengetahuan, sehingga memunculkan spesialisasi pekerjaan dan perubahan struktur di masyarakat. Pohon pengetahuan dibedakan berdasarkan 
apa yang diketahui, bagaimana cara mengetahui, dan untuk apa pengetahuan digunakan. Namun, dengan pembedaan keilmuan justru menimbulkan berbagai masalah dan kerumitan, sehingga menyebabkan sebagian orang melakukan pendekatan inter-disipliner. ${ }^{13}$ Dalam perkembangan Kesehatan reproduksi juga mempunyai pendekatan inter-disipliner yang beberapa cabang ilmu bergabung menelaah sasaran yang sama. ${ }^{16}$ Dia merupakan bagian ilmu kedokteran dan kesehatan yang secara spesifik menangani berbagai masalah repoduksi manusia dengan penanganan yang tidak semata-mata di tingkat individu, tetapi juga di tingkat masyarakat. Selanjutnya, cabang ilmu-ilmu sosiologi dan humaniora bersama ilmu-ilmu kesehatan menelaah area kesehatan reproduksi tersebut. Oleh sebab itu, pertemuan natural sciences dan social sciences dalam bahasan kesehatan menjadi relevan ketika berbagai masalah kesehatan reproduksi banyak berhubungan dengan masalah kependudukan.

\section{Ontologi}

Ontologi suatu bidang ilmu adalah hakekat pengetahuan yang menjadikan asumsi dasar suatu kebenaran bidang ilmu tertentu. ${ }^{12}$ Ontologi didefinisikan sebagai studi tentang konsep realitas yang dijelaskan oleh suatu disiplin ilmu. ${ }^{17}$ Ontologi kesehatan reproduksi adalah bidang area yang bergerak untuk memahami, mendalami dan mengembangkan pengetahuan tentang kesehatan reproduksi, termasuk penanganan berbagai masalah reproduksi manusia. Bukan hanya pada tingkat individu tetapi juga tingkat masyarakat, dapat dinyatakan bahwa reproduksi individu atau masyarakat tersebut sehat. Individu atau masyarakat mempunyai sistem reproduksi yang sehat, fungsi reproduksi yang sehat dan proses reproduksi yang sehat.

Seperti bidang kedokteran dan kesehatan lainnya, kesehatan reproduksi akan menatap manusia sebagai objek. Tubuh manusia yang disebut sebagai 'geometri tubuh' mempunyai empat dimensi, meliputi: pertama, dimensi kesinambungan waktu dengan masalah utama reproduksi; kedua, dimensi kesinambungan ruang dengan masalah utama regulasi dan kontrol populasi yang juga disebut sebagai masalah "politik"; ketiga, dimensi kemampuan untuk menahan hasrat yang merupakan persoalan internal tubuh; keempat, kemampuan merepresentasikan tubuh kepada sesama yang merupakan persoalan ekstenal tubuh. Keempat dimensi tubuh ini terkait erat dengan bidang area kesehatan reproduksi dan bidang kesehatan lain yang terintegrasi di dalamnya yaitu kesehatan seksual. ${ }^{18}$ Menurut WHO, kesehatan seksual tidak terpisahkan dari kajian kesehatan reproduksi, karena sebagai akibat munculnya berbagai penyakit menular seksual, termasuk HIV dan AIDS, peningkatan kepedulian kesehatan masyarakat terhadap berbagai kejadian ke- kerasan yang berhubungan dengan jender (gender-related violance) serta berbagai masalah disfungsi seksual. Hal tersebut menekankan pada perlu perhatian terhadap penanggulangan karena sangat mempengaruhi kesehatan dan kesejahteraan masyarakat di suatu negara. Pemenuhan hak azasi manusia dalam bentuk hak kesehatan seksual dan kesehatan reproduksi menjadi hal yang esensial. ${ }^{19}$

Bidang yang menggeluti berbagai penyakit sistem reproduksi seperti infeksi dan keganasan murni merupakan bidang ilmu kedokteran. Ketika penelusuran dilakukan terhadap penyebab infeksi atau keganasan pada sistem dan organ reproduksi, maka berbagai masalah yang menyertai dan melatarbelakanginya juga menyangkut berbagai aspek kesehatan lain, seperti gizi, sosiologi, ekonomi, antropologi dan humaniora. Kejadian kekerasan dalam rumah tangga atau perdagangan manusia (human trafficking), juga membuat kesehatan reproduksi ikut berperan. Jelaslah bahwa bidang kesehatan reproduksi tidak dapat berdiri, dia akan menelaah dan menanggulangi berbagai masalah kesehatan reproduksi bersama bidang ilmu lain. Untuk mengatasi permasalahan yang ada, mereka saling melengkapi dan mendukung dengan satu tujuan menciptakan reproduksi yang sehat.

\section{Epistemologi}

Epistemologi atau sejarah perkembangan keilmuan dalam menelaah asal mula dan ruang lingkup suatu ranah pengetahuan yang berupaya menjawab pertanyaan 'bagaimana ilmu pengetahuan didapatkan dan dibangun?'17 Dengan kata lain epistemologi adalah sarana, sumber, metoda menggunakan langkah maju menuju ilmu pengetahuan. ${ }^{12}$ Epistemologi kesehatan reproduksi bermula dari kepedulian Maria Stopes dan Margaret Sange pada kematian ibu yang tinggi di dalam masyarakat yang ternyata berhubungan dengan kelahiran yang tinggi. Teknologi pengaturan keluarga yang ditemukan kemudian, pada mulanya mendapatkan tantangan yang berkepanjangan, tetapi jasa kedua tokoh keluarga berencana dunia tersebut akhirnya diakui oleh dunia. Teknologi keluarga berencana berkembang sejalan dengan perkembangan dunia kedokteran. Pengaturan keluarga tidak terbatas pada upaya membatasi atau menjarangkan kelahiran, tetapi juga menciptakan teknologi untuk mendapatkan anak, karena tidak semua orang mempunyai kemudahan dan mampu mendapatkan keturunan secara alami. Bantuan mendapatkan keturunan bermula dari penemuan teknologi inseminasi buatan atau AI (Artificial Insemination), yang diikuti teknologi fertilisasi di luar atau IVF (In Vitro Fertilization) dan transfer embrio atau ET (Embryo Transfer). Temuan teknologi yang paling mutakhir adalah teknologi kloning. Berbagai temuan teknologi tersebut tidak dapat langsung 
diaplikasikan kepada manusia, tetapi melalui serangkaian percobaan pada hewan. Adopsi teknologi kedokteran hewan yang diakui selangkah lebih maju daripada teknologi kedokteran manusia merupakan sesuatu yang lazim, mengingat teknologi yang bertujuan untuk kemaslahatan umat manusia tujuan dari suatu ilmu pengetahuan.

Pertambahan jumlah penduduk yang merupakan keberhasilan proses reproduksi manusia bagaikan dua sisi mata uang. Di satu pihak, dia merupakan proses yang menguntungkan, di lain pihak merupakan ancaman. Reproduksi yang tidak terkendali akan mengancam persediaan sumber daya alam, sehingga memunculkan teknologi pengendalian, berbagai alat kontrasepsi. Serangkaian konferensi kependudukan, yang selalu memasukkan masalah kesehatan reproduksi ke dalam agenda pertemuan. Agenda tersebut meliputi keluarga berencana, pencanangan hak kesehatan seksual dan kesehatan reproduksi, yang diharapkan dapat diretifikasi setiap negara anggota.

Ketika kesehatan seksual berintegrasi dengan kesehatan reproduksi, maka hak-hak kesehatan seksual dan kesehatan reproduksi, yang merupakan bagian dari hakhak azasi manusia diretifikasi oleh negara. Mengabaikan hak tersebut akan berdampak pada munculnya masalah yang berakar pada kepedulian terhadap kesehatan reproduksi yang rendah. Sebagai contoh, pengabaian kesehatan reproduksi remaja berdampak pada akses pelayanan kesehatan reproduksi remaja yang rendah. Hal tersebut menjadi salah satu penyebab tingkat infeksi kasus baru berbagai penyakit menular seksual, termasuk HIV dan AIDS yang tinggi. Penyakit AIDS/HIV yang sampai kini belum ditemukan obat penyembuhnya, merupakan fakta yang seharusnya menjadi strategi andalan untuk menyadarkan remaja mencegah penularan virus yang mematikan tersebut. Obatobat sangat mahal yang hanya berguna memperpanjang usia penderita AIDS tersebut pasti tidak akan memecahkan masalah. Berbagai temuan pada rangkai penelitian di ranah kesehatan reproduksi adalah sangat berharga dan tidak dapat diabaikan dalam upaya membangun strategi pemecahan berbagai masalah kesehatan reproduksi yang ada.

\section{Aksiologi}

Aksiologi adalah nilai-nilai (values) yang merupakan tolok ukur kebenaran ilmiah yang menjadikan etik dan moral sebagai dasar normatif dalam penelitian, penggalian dan aplikasi ilmu. ${ }^{12}$ Aksiologi adalah nilai tujuan pemanfaatan dan penggunaan pengetahuan untuk meningkatkan kesejahteraan dan kebutuhan hidup manusia. Sejalan dengan perkembangan zaman, ketika nilai dan norma yang berlaku di masyarakat dipengaruhi oleh situasi dan kondisi negara pada suatu ketika, maka pe- rilaku manusia atau masyarakat akan mengadopsi keserbabolehan yang ada. Perilaku yang berhubungan dengan kesehatan, seperti tidak membuang sampah sembarangan, melaporkan unggas yang mati mendadak segera, atau mencuci tangan merupakan hal umum yang mudah diadopsi oleh masyarakat. Namun, berbagai fakta empiris menunjukkan bahwa kepatuhan masyarakat dipengaruhi oleh banyak faktor. Sementara, berbagai perilaku yang tabu dibicarakan secara publik, membutuhkan regulasi lebih rumit yang mengundang pro dan kontra. Seperti undang-undang pornografi dan pornoaksi yang hingga kini tidak diketahui keberadaan dan kelanjutannya.

Tampaknya, kepedulian negara terhadap perilaku seksual masih dilingkupi oleh tradisi tabu. Padahal informasi dini yang baik dan benar akan membekali remaja dengan sikap, pengertian cara pengambilan keputusan terbaik untuk diri sendiri. Pengertian bahwa tubuh adalah area privasi diri, memberikan rasa memiliki dan menyayangi. Hal tersebut dapat mencegah tindakan gegabah, seperti melakukan seks sebelum menikah, mencoba obat-obat terlarang, atau bahkan terlibat dalam kegiatan pornoaksi. Banyak penelitian membuktikan bahwa pendidikan kesehatan reproduksi pada remaja justru menjauhkan remaja dari prilaku coba-coba. Dengan memberitahu berbagai akibat yang terjadi jika salah melangkahkan, diharapkan remaja berfikir jernih untuk melakukan berbagai tindakan yang berisiko berbahaya terhadap kesehatan.

Kesehatan reproduksi merupakan ranah terapan keilmuan kedokteran dan kesehatan yang berkembang dengan dukungan dan integrasi berbagai ranah keilmuan lain, meliputi ilmu farmasi, gizi, promosi kesehatan, teknologi kedokteran, dan teknologi informasi yang secara canggih menginformasikan temuan dan terobosan baru di bidang kesehatan umum dan kesehatan reproduksi.

\section{Perkembangan}

Program kesehatan reproduksi terkini tidak dapat muncul dan tak dapat dipisahkan dengan kegiatan berbagai program kependudukan. Angka kematian ibu yang tinggi, peningkatan kasus HIV/AIDS khususnya di kalangan remaja, merupakan pemicu perkembangan teknologi diranah kesehatan reproduksi, seperti penemuan berbagai obat penunjang penderita AIDS, penanggulangan masalah infertilitas dengan teknologi kloning. Bagian ini akan membahas perkembangan ranah kesehatan reproduksi yang diawali dengan kepedulian dunia pada angka fertilitas yang tinggi yang memicu penyelenggaraan konferensi kependudukan dunia yang berlanjut dengan bahasan tentang hak kesehatan reproduksi dan kesehatan seksual yang merupakan hak azasi manusia. Terakhir adalah tentang perkembangan teknologi ke- 
sehatan reproduksi.

Pada ICPD Cairo 1994, dicetuskan pergeseran paradigma kependudukan dari paradigma 'pengendalian jumlah' menjadi 'pemenuhan hak dan kepentingan individu'. Isu-isu kesetaraan jender, pemberdayaan perempuan, serta terobosan hak kesehatan reproduksi mulai dikumandangkan disini. Program aksi (programme of action) ICPD Cairo tersebut mencakup 16 Bab, meliputi Pembukaan; Prinsip-prinsip dasar; Hubungan antara populasi, Kesinambungan pertumbuhan ekonomi dan pembangunan; kesetaraan jender, keadilan dan pemberdayaan perempuan; peran, hak, komposisi dan struktur keluarga; pertumbuhan dan struktur populasi; hak reproduksi dan kesehatan reproduksi; kesehatan, kesakitan dan kematian; distribusi populasi, urbanisasi, dan migrasi internal; migrasi internasional; populasi, pembangunan dan pendidikan; teknologi, riset dan pengembangan; aksi nasional; kerja sama internasional; kemitraan dengan sektor non pemerintah; dan tindak anjut dari hasil konferensi. Terdapat beberapa bab yang berkaitan dengan kesehatan, dan kesehatan reproduksi. Berikut adalah Bab-bab yang berisi muatan-muatan bidang area kesehatan reproduksi.

Bab Pembukaan paragraf 1.8 dan 1.12 menjelaskan keberhasilan negara anggota dalam kurun waktu 20 tahun terakhir menangani berbagai masalah kependudukan. Hal tersebut meliputi penurunan angka kelahiran, angka kematian, peningkatan level pendidikan penghasilan, dan status ekonomi, terutama pada perempuan. Keberhasilan yang paling nyata adalah pergeseran pandangan penentu kebijakan menyikapi konsep baru kesehatan reproduksi. Termasuk sikap terhadap isu keluarga berencana dan kesehatan seksual yang memberikan komitmen terhadap POA hasil ICPD Kairo. Pada Bab Prinsip-prinsip Dasar, dari lima belas prinsip yang diajukan, maka isu-isu kesehatan reproduksi terdapat pada Prinsip 1, 2, 4, 8, 9 dan 11, mulai dari isu hak azasi manusia, pemberdayaan perempuan, penyediaan akses layanan kesehatan reproduksi, kesetaraan jender, perkawinan tanpa paksaan, hingga perlindungan negara atas eksploitasi dan perdagangan manusia.

Bab VII tentang Hak Reproduksi dan Kesehatan Reproduksi dengan program asksi meliputi lima aspek kesehatan reproduksi, untuk hak reproduksi dan kesehatan reproduksi, keluarga berencana, penyakit menular seksual dan pencegahan HIV, seksualitas dan hubungan antar jender, remaja. Setiap POA mempunyai tujuan yang harus diimplementasikan oleh setiap negara peserta.

Kelima tujuan POA tersebut secara sinergi diimplementasikan dalam berbagai program kesehatan reproduksi di negara anggota konferensi. Di Indonesia, program kesehatan reproduksi mengadopsi rekomendasi stra- tegi regional WHO untuk negara-negara anggota ASEAN meliputi paket kesehatan reproduksi esensial (PKRE) dan paket kesehatan reproduksi komprehensif (PKRK). PKRE terdiri dari Kesehatan Ibu dan Anak, Keluarga Berencana, Pencegahan dan Penanggulangan ISR/PMS/HIV dan kemandulan, dan Kesehatan Reproduksi Remaja. PKRK adalah mencakup PKRE ditambah dengan Pelayanan dan Penanganan masalah Lansia. Disamping itu, penanggulangan masalah kesehatan ibu dan anak berbagai program berawal dari program Gerakan Sayang Ibu (GSI) yang sudah dilakukan. Namun, predikat Indonesia sebagai negara nomor satu dengan angka kematian ibu (AKI) yang tertinggi masih melekat. AKI Indonesia yang terkini masih sekitar 307 per 100.000 kelahiran hidup (SDKI, 2002-2003). Angka tersebut jauh lebih tinggi dari Malaysia (50 per 100.000 kelahiran hidup dan Singapura (8 per 100.000 kelahiran hidup). Angka tersebut mengekspresikan perhatian penentu kebijakan yang belum peduli pada kesejahteraan ibu, yang dapat diupayakan melalui strategi kesehatan reproduksi.

Ketika hak kesehatan reproduksi harus terpenuhi, berarti harus mencakup hak mendapatkan manfaat dari kemajuan ilmu pengetahuan. Masalah paling mendasar ketika angka kematian ibu adalah belum ditemukan teknik pencegahan pertemuan sperma dan sel telur. Upaya yang paling tidak manusiawi adalah aborsi yang menjadi cara pintas untuk mencegah penambahan anggota keluarga. Ketika berbagai temuan tersebut semakin berkembang, tercipta berbagai metode kontrasepsi mencakup metoda hormonal, penggunaan alat, dan metode operasi. Sebaliknya, teknologi untuk pasangan dengan tingkat kesuburan memenuhi hak produktif pasangan tersebut. Berbagai pengobatan yang mencakup sinkronisasi kesuburan, inseminasi buatan atau AI (Artificial Insemination), fertilisasi di luar atau IVF (In Vitro Fertilization) dan transfer embrio atau ET (Embryo Transfer), serta teknologi kloning, merupakan upaya pengendalian.

Ketika dunia farmasi berkembang bersamaan masalah yang terkait reproduksi, obat-obatan penanggulangan berbagai penyakit menular seksual juga berkembang, khususnya obat-obat penanggulangan infeksi HIV dan AIDS. Meskipun, obat penyembuhan penyakit AIDS belum ditemukan, tetapi obat-obat yang memperpanjang hidup penderita terus dikembangkan dan diproduksi, dengan harga yang sangat mahal. Untuk itu, peran bidang lain seperti promosi kesehatan saling melengkapi program kesehatan reproduksi. Saat ini infeksi baru HIV terbanyak adalah sumbangan kaum muda yang menggunakan obat-obat terlarang melalui jarum suntik. Sudah saatnya negara memfokuskan diri dalam pencegahan kasus baru narkoba suntik yang pada akhirnya akan menekan kasus baru infeksi HIV. 


\section{Kesimpulan}

Salah satu pemenuhan hak azasi manusia adalah tercapainya hak-hak kesehatan, yang mencakup hak kesehatan reproduksi. Dari perjalanan sejarah panjang dunia kesehatan, ranah kesehatan reproduksi mempunyai andil yang besar. Capaian tersebut diraih bersama dengan berbagai ranah ilmu pengetahuan yang lain. Kegiatan reproduksi yang menghasilkan manusia baru tidak lepas dari persiapan rumit dan terencana. Filosofi kesehatan reproduksi diadopsi dari definisi kesehatan reproduksi yang dicanangkan oleh WHO pada ICPD ke-5 di Cairo tahun 1994, yaitu membebaskan manusia dari gangguan sistem, fungsi, dan proses reproduksi yang merupakan hak setiap individu laki-laki dan perempuan. Dalam kesehatan reproduksi, kesetaraan merupakan faktor utama yang sangat menunjang pencapaian reproduksi sehat. Teknologi yang tercipta dan dimanfaatkan tidak hanya memuaskan pihak tertentu, tetapi haruslah dinikmati oleh semua individu tanpa ada batas. Ketika teknologi kesehatan reproduksi yang diciptakan tersebut tidak memberikan rasa nyaman, perlu dipertimbangkan pandangan dari bidang lain.

\section{Daftar Pustaka}

1. Situs Today in Science. [diakses tanggal 16 Januari 2008]. Diunduh dari: http://www.todayinsci.com/10/10_02.htm.

2. Your friend, philosopher and guide. [diakses tanggal 16 Januari 2008]. Diunduh dari: http://www.sitagita.com/view.asp?id=6725.

3. Sejarah perkembangan keluarga berencana dan program kependudukan. Jakarta: Badan Koordinasi Keluarga Berencana Nasional: 1981.

4. Lewis H J. Woman History. [diakses tanggal 16 Januari 2008]. Diunduh dari: http://womenshistory. about.com/library/bio/blbio_margaret _sanger.htm.

5. WHO. Dokumen ICPD. [diakses tanggal 26 Oktober 2007]. Diunduh dari: http://www.who.org.

6. [diakses tanggal 4 Febrari 2008]. Diunduh dari: http://en.wikipedia.
org/wiki/Cloning.

7. Trusted health information for you. [diakses tanggal 4 Febrari 2008]. Diunduh dari: http://www.nlm.nih.gov/medlineplus/cloning.html.

8. Preamble to the Constitution of the World Health Organization as adopted by the International Health Conference, New York, 19-22 June, 1946; signed on 22 July 1946 by the representatives of 61 States (Official Records of the World Health Organization, no. 2, p. 100) and entered into force on 7 April 1948.

9. [diakses tanggal 28 Januari 2008]. Diunduh dari: http://www.thefreedictionary.com/reproductive.

10. [diakses tanggal 28 Januari 2008]. Diunduh dari: http://www.rho.org/html/definition_.htm

11. Situs Centre for Reproduktive Rights. [diakses tanggal 29 Januari 2008]. Diunduh dari: http://www.reproductiverights.org/ww_iss_reprohealth.html.

12. Wibisono, Koento. Hand-out Kuliah S3 Filsafat Ilmu tahun akademik 2007/2008.

13. Suriasumantri, Jujun S. Filsafat ilmu - sebuah pengantar populer. Jakarta: Pustaka Sinar Harapan; 1999.

14. The New Brittanica Encyclopedia. [diakses tanggal 4 Februari 2008]. Diunduh dari: www.britannica.com.

15. Modul on-line untuk SMA-Pustekom. [diakses tanggal 4 Februari 2008]. Diunduh dari: http://www.e-dukasi.net/mol/ mo_full.php?moid=75 \&fname=cabang.htm

16. Gie, The Liang. Pengantar filsafat ilmu. Yogyakarta: Liberty; 2000.

17. Dharmawan, Arya Hadi. Dinamika sosio-ekologi pedesaan: Perspektif dan pertautan keilmuan ekologi manusia, sosiologi lingkungan dan ekologi politik. Solodarity: Jurnal Transdisiplin Sosiologi, Komunikasi, dan Ekologi Manusia. 2007;1(1).

18. Turner, Bryan S. dalam Nuraini Juliastuti. Studi tubuh. Newslatter Kunci. Yogyakarta; 1999. [edisi 1 Juli 1999, diakses tanggal 4 Februari 2008]. Diunduh dari: http://www.kunci.or.id/esai/nws/01/studi_tubuh.htm.

19. WHO. Sexual health - a new focus for WHO. Progress in Reproductive Health Research. No. 67. 2004. Department of Reproductive Health and Research. Geneva, Switzerland: World Health Organization; 2004. 